\title{
Genes Polymorphism in Children with Diseases of the Nervous System Living in the Conditions of the Far North of Russia
}

\author{
A.A. Mazunina ${ }^{1, *}$, O.V. Dolgikh ${ }^{1}$ and K.P. Luzhetsky ${ }^{1}$ \\ ${ }^{1}$ Federal Scientific Center for Medical and Preventive Health Risk Management Technologies, Perm, Russia \\ *Corresponding author. Email: alena-osa@.ru
}

\begin{abstract}
A comparative genetic examination of children with varying degrees of asthenization of the nervous system, living in the Far North of Russia was carried out. The polymerase chain reaction method on BioRAD CFX96 Real Time System was used to study the following polymorphisms: A1166C of AGTR1 angiotensin II receptor gene (rs5186), C1377T of calcitonin receptor gene CALCR (rs1801197), T/C of the clock period gene CLOCK (rs1801260) and G4682A of tumor necrosis factor (TNF) gene (rs1800629). An associative relationship between these polymorphisms and the pathology of the nervous system in the climatic and geographic conditions of the Far North was established. Among the child population living in the Far North and having nervous system pathology a significant increase in the prevalence of variant alleles of genes providing the genetic determination of the development of asthenic-vegetative syndrome was shown due to angitensinogen associated processes of impaired cerebral vascular tone (AGTR1 rs5186), imbalance of seasonal and circadian rhythms underlying the processes of fatigue (CLOCK rs1801260), as well as impairment of optimal reception of processes of cell membrane regulation of the apoptosis procedure (CALCR rs1801197, TNF rs1800629).
\end{abstract}

Keywords: genes polymorphism, nervous system diseases, asthenization, Far North

\section{PAGE LAYOUT}

Both preservation and strengthening of the health of the child population in the North of Russia is acquiring great importance. Today, the northern territories are identified as a special zone that requires close attention, since the proportion of chronic diseases among children and adolescents of the Far North, which tends to increase with age, determines the relevance of forecasting and high-quality implementation of preventive measures at the population level [4].

The development of all morphological and functional structures of the body is completed in the adolescence and the individual, genetically determined program of the body's development is finalized [12].

In the Far North, the autonomic nervous system is under increased stress, since, along with the endocrine system, it provides adaptive restructuring [8]. Carrying out modulatory-regulatory and trophic control over the visceral systems, the autonomic nervous system optimizes the functioning of the body's functional systems, participates in the mechanisms of compensation for disturbed functions [9]. Thus, the sympathetic nervous system is directly involved in adjustment to cold [8].

During the polar day an increased excitability of the central nervous system, irritability, sleep disturbances, various autonomic disorders, primarily of a cardiogenic nature dominate $[8,11,12]$.

The aim of the study was to study the features of genetic polymorphism associated with disorders of the nervous system in the child population living in the Far North.

\section{METHODS AND MATERIALS}

In order to study the genetic status of children at risk of developing pathology of the nervous system, two 
groups of children living in the Far North were examined. The group under study consisted of 72 children (39 boys, 33 girls) 3-12 years old with pathology of the nervous system (disorders of the autonomic nervous system) living in the Arctic. The group under study consisted of 64 children (31 boys, 33 girls) 3-10 years old, living in the conditions of the North, but not presenting complaints of asthenia.

The DNA of patients was exported from the buccal epithelium using Sorb-AM (AmpliPrime, Russia). After that, the genotypes were determined for polymorphisms A1166C of the AGTR1 angiotensin II receptor gene (rs5186), C1377T of calcitonin receptor gene CALCR (rs1801197), T/C of hourly period gene CLOCK (rs1801260) and G4682A of tumor necrosis factor gene (TNF) (rs1800-29) using the test systems of the company Syntol (Russia). Genotyping was performed using the polymerase chain reaction (PCR) technique in real time applying the allelic discrimination method in the software FRT-Manager on CFX96 system (BioRad, USA).

The level of carcino-embryonic antigen was investigated using CEA-ELISA kit for quantitative determination of the concentration of carcinoembryonic antigen in serum (plasma) blood by the method of enzyme-linked immunosorbent assay with the help of Elx808 analyzer (BioTek, USA).

The calculation of the distribution of frequencies of genotypes and alleles among group under study and the control group was carried out using the Equilibrium Hardy-Weinberg online software $(p>0.05)$. To assess the associations of alleles and genotypes with the risk of developing diseases, the $\mathrm{p}$-level of significance $(\mathrm{p}<0.05)$

and the odds ratio (OR) with a $95 \%$ confidence interval (CI) calculated in Microsoft Excel were used.

The results of the study were also processed using the Statistica 6.0 software. The arithmetic mean (M) and the error of the mean $(\mathrm{m})$ were calculated. The Student's t-test was used to compare groups in terms of quantitative characteristics. Differences were considered significant at $\mathrm{p}<0.05$.

\section{RESULTS}

The results of distribution evaluation of genotype frequencies for their correspondence to the HardyWeinberg population equilibrium in both groups did not reveal any deviations from the Hardy-Weinberg equation in the samples ( $\mathrm{p}>0.05$, Table 1$)$.

The correspondence of results to the HardyWeinberg equilibrium made it possible to analyze genetic differences using the multiplicative model of inheritance (Table 2)

Table 1. Correspondence of the distribution of results to the Hardy-Weinberg equilibrium for the groups of the studied genes

\begin{tabular}{|l|l|l|}
\hline Gene & p for study group & p for control group \\
\hline AGTR1 (rs5186) & 0.66 & 0.90 \\
\hline $\begin{array}{l}\text { CALCR } \\
\text { (rs1801197) }\end{array}$ & 0.13 & 0.56 \\
\hline $\begin{array}{l}\text { CLOCK } \\
\text { (rs1801260) }\end{array}$ & 0.98 & 0.66 \\
\hline TNF (rs1800629) & 0.98 & 0.69 \\
\hline
\end{tabular}

Table 2. Results of analysis of multiplicative inheritance models for the studied genes

\begin{tabular}{|l|l|l|l|l|l|}
\hline \multirow{2}{*}{ Gene } & Alleles & $\begin{array}{l}\text { Study } \\
\text { group }\end{array}$ & Control group & OR (95\% CI) & P \\
\hline \multirow{3}{*}{ CALCR (rs1801197) } & Allele A & 0.664 & 0.789 & $0.53(0.31-0.91)$ & 0.02 \\
\cline { 2 - 6 } & Allele C & 0.336 & 0.211 & $1.89(1.10-3.21)$ & $0.50(0.30-0.85)$ \\
\hline \multirow{2}{*}{ CLOCK (rs1801260) } & Allele C & 0.619 & 0.764 & $2.00(1.18-3.34)$ & 0.01 \\
\cline { 2 - 6 } & Allele T & 0.381 & 0.236 & $0.56(0.34-0.95)$ & $1.78(1.05-2.97)$ \\
\hline \multirow{2}{*}{ TNF (rs1800629) } & Allele T & 0.615 & 0.739 & 0.03 \\
\cline { 2 - 6 } & Allele C & 0.385 & 0.261 & $2.72(1.15-6.33)$ & 0.04 \\
\hline
\end{tabular}


When analyzing the distribution of allele frequencies of gene polymorphisms in the groups of unhealthy and relatively healthy people, significant differences were revealed, confirming the association of the trigger genes AGTR1 (rs5186), CALCR (rs1801197), CLOCK (rs1801260), and TNF (rs1800629) with the diseases of the nervous system. The occurrence of variant alleles, including the $\mathrm{C}$ allele of the AGTR1 gene (rs5186), the $\mathrm{T}$ allele of the CALCR gene (rs1801197), the C allele of the CLOCK gene (rs1801260), and the A allele of the TNF gene (rs1800629) are significantly higher by 1.6 , 1.6, 1.5 and 2.4 times, respectively, compared to the control group $(\mathrm{p}<0.05)$.

An analysis was carried out, associated with polymorphic changes in the genes of calcitonin and tumor necrotic factor, as well as the level of carcinoembryonic antigen in the blood serum, the expression of which is associated with the proliferative processes of the 3rd phase of the inflammatory process. The CEA value corresponded to the limits of the reference interval, but when compared between the groups, a significant increase in its level was observed in children with pathology of the autonomic nervous system -1.4 times relative to the control group ( $<$ <.05) (Table 3$)$.

Table 3. The level of carcino-embryonic antigen in blood serum in children with the autonomic nervous system pathology

\begin{tabular}{|l|l|l|l|}
\hline $\begin{array}{l}\text { Indicator, unit of } \\
\text { measure }\end{array}$ & $\begin{array}{l}\text { Group under } \\
\text { study }\end{array}$ & $\begin{array}{l}\text { Control } \\
\text { group }\end{array}$ & $p$ \\
\hline $\begin{array}{l}\text { CEA (Carcino } \\
\text { Embryonic } \\
\text { Antigen), } \mathrm{H} / \mathrm{CM}^{3}\end{array}$ & $1.851 \pm 0.418$ & $1.304 \pm 0.324$ & 0.04 \\
\hline
\end{tabular}

\section{DISCUSSION}

The AGTR1 gene encodes angiotensin II receptor type 1 . This receptor type is predominantly located in the smooth muscle cells of blood vessels and heart, kidneys and adrenal glands. Angiotensin is the main effector peptide of renin-angiotensin-aldosterone system, which regulates water and salt metabolism [7].

Patients with verified diagnoses of diseases of the circulatory system, the frequency of the "mutant" $1166 \mathrm{C}$ locus and the pathological homozygous C1166C genotype of the AGTR1 gene were statistically significantly increased. The risk of developing cardiovascular diseases among the $1166 \mathrm{C}$ allele carriers increases 3.8 times, and in the case of the homozygous "mutant" C/C genotype it increases 10.4 times, which confirms the association of the studied A1166C polymorphism and the $\mathrm{C} / \mathrm{C}$ genotype with an increased risk of diseases development of the circulatory system [10]. In the group of individuals with different forms of ischemic heart disease, the consequences of coronary atherosclerosis, the frequency of the $1166 \mathrm{C}$ allele and the $\mathrm{C} / \mathrm{C}$ genotype AGT2R1 significantly exceeds those for the control group. In $\mathrm{C} 1166 \mathrm{C}$ homozygotes and the $1166 \mathrm{C}$ allele carriers, the risk of coronary heart disease increases 17.37 times and 5.14 times, respectively [2].

There is a high probability of the development of pathology of the autonomic nervous system regarding the examined group of children living in the Far North, associated with the genetic determinism of disorders of the tone of cerebral vessels carrying the angiotensinogen receptor. The association of polymorphism with the risk of ischemic stroke has been established in several casecontrol studies. Caucasians of Italy with allele C, especially those with hypertension $(\mathrm{OR}=2.0)$, have an increased risk of ischemic stroke [6].

The CALCR gene encodes calcitonin receptor membrane proteins on osteoclasts, kidney and liver cells. The presence of the $\mathrm{T}$ allele in the $\mathrm{C} 1377 \mathrm{~T}$ polymorphism can lead to a decrease in bone density, a decrease in the activation of the calcium receptor, which, under conditions of a deficit of insolation, leads to an increased risk of imbalance in the immune regulation of the cell life cycle, its atopic rearrangement and asthenization $[14,18]$.

The circadian system consists of a set of clock genes including PER, CLOCK, BMAL1, and CRY. Violation of this system contributes to the development and generation of proliferative processes [16]. The CLOCK gene (rs1801260), encoding the CLOCK transcription factor, plays a key role in the regulation of circadian and seasonal rhythms, energy consumption, and fatigue [1]. Polymorphism in this gene can be associated with behavioral changes in certain populations, as well as obesity and metabolic syndrome [15]. There is also evidence that the presence of the C allele of the CLOCK gene (rs1801260) affects myelination processes, regulating the quality and quantity of sleep $[13,17]$

For alleles and genotypes of the G4682A polymorphism of the TNF gene (rs1800629), the frequency in Caucasians is as follows: the G/G genotype occurs in $64-84 \%$ of cases, G/A occurs in 14-31\% of cases, and A/A occurs in $0.5-4.5 \%$ of cases. In Caucasians of Siberia, the frequency of allele $\mathrm{A}$ is $10.2 \%[5]$.

The maternal polymorphic variant of the TNF gene has significant associations with congenital malformations in fetus and newborn (CMFN). It was stated that the carriage of the A allele and the A/A genotype of the TNF gene among women had a risk of the formation of CMFN (OR $=1.7$ and $\mathrm{OR}=6.3$, respectively). When studying the contribution of the $\mathrm{G} \rightarrow \mathrm{A}$ polymorphic locus of the $T N F$ gene of mother to the formation of child's congenital malformation, depending on its morphological affiliation, it was found out that the maternal polymorphism $\mathrm{G} \rightarrow \mathrm{A}$ of the TNF gene was associated with the formation of a congenital malformation of the central nervous system of a child. It 
was revealed that the allele $\mathrm{A}$ and genotype $\mathrm{A} / \mathrm{A}$ of the TNF gene among women could increase the likelihood of child's congenital CNS anomaly development up to 14 times [3].

\section{CONCLUSION}

Thus, a significant increase in the variant alleles of the AGTR1 (rs5186), CALCR (rs1801197), CLOCK (rs1801260), and TNF (rs1800629) gene regions was shown among the children population with nervous system pathologies living in the Far North of Russia. Genetic determination of the asthenia scenario is provided due to angitensinogen-associated processes of disturbance of the tone of cerebral vessels (AGTR1), imbalance of seasonal and circadian rhythms underlying the processes of fatigue (CLOCK), as well as disturbance of optimal reception of processes of cellular membrane regulation of the apoptosis procedure (CALCR, TNF) with the activation of the inflammatoryproliferative mechanism (CEA), the development of disorders of the nervous system (astheno-vegetative syndrome) in children living in the Far North of Russia.

\section{REFERENCES}

[1] I.I. Akhmetov, L.D. Mustafina, E.S. Nasibulina, Medical and genetic support for children and youth sports, Pract. Med. 7(62) (2012) 62-66.

[2] T.M. Ashkanova, D.V. Muzhenya, A.R. Pshidatok et al., Predictive role of A1166C polymorphisms of the angiotensin II receptor type 1 (AGT2R1) gene in coronary atherosclerosis in residents of the Republic of Adygea, Rus. J. of Cardiol. 10(126) (2015) 19-23.

[3] L.A. Gordeeva, O.A. Glushkova, E.N. Voronina et al., Associations of maternal polymorphisms of cytokine genes (IL1B, IL1RN, TNF, IL4, IL6) with congenital malformations in the fetus and newborn, Immunol. 6 (2013) 298-304.

[4] M.G. Dyachkova, N.G. Belyakov, The main trends in the sustainability of health of children and adolescents living in the Far North of the Russian Federation, Hum. Ecol. 4 (2005) 19-23.

[5] M.V. Zykov, O.A. Makeeva, M.V. Golubenko et al., Investigation of rs1800629 (G-308A) polymorphism of the TNF gene in patients with ST-segment elevation myocardial infarction, Rus. J. of Cardiol. 10(114) (2014) 13-18.

[6] V.I. Korchagin, K.O. Mironov, O.P. Dribnokhodova et al., The role of genetic factors in the formation of an individual predisposition to ischemic stroke, Ann. of Clin. and Experim. Neurol. 10(1) (2016) 65-75.
[7] N.V. Kokh, A.A. Slepukhina, G.I. Lifshits, Arterial hypertension: molecular genetic and pharmacogenetic approaches, Pharmacogenetics and pharmacogenomics 2 (2015) 4-8.

[8] S.A. Lytaev, E.A. Tolstova, Vegetative status in arterial hypertension in indigenous inhabitants of the Far North and migrants, Pediatr. 7(3) (2016) $56-62$.

[9] T.V. Maltseva, N.S. Polovodova, Peculiarities of the immune status in different variants of vegetative support in children and schoolchildren living in the Far North Pediatrics, J. them. G.N. Speransky 89(4) (2010) 122-126.

[10] D.V. Muzhenya, A.R. Tuguz, S.P. Lysenkov et al., The role of polymorphism of genes of the components of the renin-angiotensin system in the development of cardiovascular diseases, overweight and obesity in residents of the Republic of Adygea, Bull. of St. Petersburg Univ., Ser. 11, Med. 13(4) (2018) 344-354.

[11] L.E. Panin, Homeostasis and problems of circumpolar medicine (methodological aspects of adaptation), Siber. Sci. Med. J. 30(3) (2010) 6-11.

[12] N.S. Polovodova, T.V. Maltseva, Features of the immune status in adolescents of the Yamal region with different directions of vegetative tone, Bull. of the Volgograd State Med. Univ. 2(30) (2009) 3942 .

[13] I. Bollettini, E.M. Melloni, V. Aggio et al., Clock genes associate with white matter integrity in depressed bipolar patients, Chronobiol. Int. 34(2) (2017) 212-224.

[14] National Center for Biotechnology Information, Calcitonin receptor [Homo sapiens (human)]. Retrieved from: https://www.ncbi.nlm.nih.gov/gene/?term=CALCR \%20\%28C1377T\%2C\%20rs1801197\%29\&utm_so urce=gquery\&utm_medium $=$ search

[15] National Center for Biotechnology Information, Clock circadian regulator [Homo sapiens (human)]. Retrieved

from: https://www.ncbi.nlm.nih.gov/gene/?term=CLOCK $\% 20 \% 28 \mathrm{~T} / \mathrm{C} \% 2 \mathrm{C} \% 20 \mathrm{rs} 1801260 \% 29 \&$ utm_source =gquery\&utm_medium $=$ search

[16] C. Garufi, E. Giacomini, A. Torsello et al., Gender effects of single nucleotide polymorphisms and miRNAs targeting clock-genes in metastatic colorectal cancer patients (mCRC), Sci. Reports 26 (2016) 34006.

[17] A.R. Ozburn, K. Purohit, P.K. Parekh et al., Functional Implications of the CLOCK 3111T/C 
Single-Nucleotide Polymorphism, Front. in Psychiatry 7 (2016) PMC4838618.

[18] A. Zimmermann, R.A. Popp, H. Rossmann et al., Gene variants of osteoprotegerin, estrogen-, calcitonin- and vitamin D-receptor genes and serum markers of bone metabolism in patients with Gaucher disease type 1, Therap. and Clin. Risk Manag. 14 (2018) 2069-2080. 